\title{
The Effect of Wrist Kinesiotaping on Hand Motor Exercise in Fine Motor Skill for Children with Cerebral Palsy
}

\author{
Nur Dewi Anggraini, Erna Setiawati
}

Department of Physical Medicine and Rehabilitation, Diponegoro University, Semarang, Indonesia

\begin{abstract}
Introduction: Kinesiotaping (KT) is one of current method that being used for hands problems in cerebral palsy. The purpose of this study was to evaluate the effect of kinesiotaping at wrist combined with hand motor exercise in fine motor skill for children with cerebral palsy.

Methods: The design was simple randomized controlled study pre and post intervention. There were 18 children who divided into kinesiotaping and control group. Subjects in the KT group received hand motor exercise and wrist kinesiotaping. Subjects in control group received only hand motor exercise. Both groups received the exercise for 4 weeks. There were difference in the MACS score which is used to measure fine motor skills in this study. Pre and posttest scores were collected before applying kinesiotaping and after 4 weeks of intervention.

Results: Both groups showed an increase in MACS score after 4 weeks intervention. For MACS score, there was statistically significant difference in KT group $(\mathrm{p}=0.025)$, but not statistically significant in control group $(\mathrm{p}=0.083)$.
\end{abstract}

Conclusion: Wrist kinesiotaping can be used for adjunct therapy combined with conventional hand motor exercise for improving manual ability in the hand and fine motor skill in cerebral palsy.

Keywords: Cerebral palsy, fine motor skill, wrist kinesiotaping. 


\section{ABSTRAK}

Pendahuluan: Kinesiotaping (KT) merupakan salah satu metode terbaru yang digunakan untuk mengatasi masalah pada tangan pada palsi serebral. Penelitian ini bertujuan untuk mengevaluasi efek kinesiotaping pada pergelangan tangan yang dikombinasikan dengan latihan motorik tangan pada kemampuan motorik halus anak dengan palsi serebral.

Metode: Desain penelitian ini adalah uji acak sederhana terkontrol sebelum dan setelah intervensi. Terdapat 18 anak palsi serebral yang dibagi menjadi dua kelompok (kelompok kinesiotaping dan kelompok kontrol). Peserta dalam kelompok KT mendapatkan latihan motorik tangan dan kinesiotaping pada pergelangan tangan. Peserta dalam kelompok kontrol hanya mendapatkan latihan motorik tangan saja. Kedua kelompok menerima latihan selama 4 minggu. Terdapat perbedaan pada skor MACS yang digunakan untuk mengukur keterampilan motorik halus pada penelitian ini. Penilaian skor MACS dilakukan sebelum pemasangan kinesiotaping dan setelah 4 minggu intervensi.

Hasil: Kedua kelompok menunjukkan perbaikan pada skor MACS setelah 4 minggu intervensi. Pada skor MACS terdapat perbedaan yang signifikan secara statistik pada kelompok KT dengan $p=0.025$, namun tidak terdapat perbedaan yang signifikan secara statistic pada kelompok kontrol $(\mathrm{p}=0.083)$.

Simpulan: Pemasangan kinesiotaping pada pergelangan tangan dapat digunakan sebagai terapi tambahan pada latihan motorik tangan konvensional untuk memperbaiki kemampuan manual tangan dan motorik halus pada palsi serebral.

Kata Kunci: Kemampuan motorik halus, kinesiotaping pergelangan tangan, palsi serebral.

Correspondent Detail:

\section{Erna Setiawati}

Email : roswithaerna@fk.undip.ac.id

Department of Physical Medicine and

Rehabilitation,

Faculty of Medicine Diponegoro University

Semarang, Indonesia

\section{INTRODUCTION}

Cerebral palsy (CP) is a permanent disorders of developmental movement and posture that causing activities limitation, which are associated with the disorder that is not progressive in immature brain. ${ }^{1,2}$ The incidence was 2 to 3 per 1,000 births. The physical disability in children are mostly caused by Cerebral Palsy. ${ }^{1,3}$
About $83 \%$ of cerebral palsy involved the upper limb, with $36 \%$ experienced hand contractures and $69 \%$ experienced decreased hand control. ${ }^{2}$ The motor involvement pattern in upper limb varies according to the affected muscles, the spasticity or dystonia and age of patient. ${ }^{2,4,5}$ The wrist flexion-pronation contracture was one of pattern that is more common than others. ${ }^{2,5}$ This condition will affect the range of motion in wrist joint and motor skills, specifically fine motor skills in everyday activities. ${ }^{4,6}$

The interaction between proprioceptive, visual perception, and tactile with fine motor functions are factors that determine the effective of hand function in everyday activities., ${ }^{2,45}$ Wrist muscles may effect digital skill for manual activities. The basic requirement for 
this include the control capacity for fingers independently, somatosensory system to guide movements of the finger, and the transform ability. ${ }^{4,5}$

Kinesiotaping is one of current method that has been used for hands problems in cerebral palsy. Kinesiotaping, is an elastic adhesive tape that applied to the skin surface directly. ${ }^{7}$ It is typically used to facilitate or inhibit the function of muscles, increase proprioceptive and sensory feedback, stimulate mechanoreceptors, help to support the joint structures and alignment, and also reduces the pain. ${ }^{7,8,9}$

Kinesiotaping is easy to apply, inexpensive, non-invasive and effective when combined with hand motor exercise. Razti studied the addition of kinesiotaping to hand motor exercise for 2 days. They assessed the shortterm effects of kinesiotaping on handgrip strength and wrist range of motion. They found significant change in intervention group compared to control group. ${ }^{6}$

Therefore, we were interested in knowing the effect of kinesiotaping on the wrist extensor muscles in fine motor in CP. We used Manual Ability Classification System (MACS) score to assess fine motor skill. MACS is a system of classification for cerebral palsy how they manipulate or handle objects with hands in everyday activities. ${ }^{10,11}$ It can evaluate the overall ability of children to handle daily objects, not the each hand function. MACS encompass all of functional limitations spectrum that found in cerebral palsy children and all sub-diagnoses. ${ }^{10,11}$

\section{METHOD}

The study was done in Yayasan Penyandang Anak Cacat (YPAC) in Semarang on August to September 2019. This was simple randomized controlled pre and post experimental design. Subjects were divided into kinesiotaping (KT) and control group. For the inclusion criteria, we included children with cerebral palsy on age between 8 to 14 years old, had wrist flexion deformity without passive range of motion (ROM) limitation on upper extremity, had wrist spasticity less than two based on Asworth scale, could understand simple instruction (minimal IQ 35 from school database).

The participants were excluded if they had visual and auditory disorder uncorrected so they could not follow the instructions, got botox or muscle relaxant therapy in last 6 months, had wrist kinesiotaping in last 1 week, underwent surgery procedure on wrist, had open wounded at wrist and hand, had active seizure disorder, had allergic reaction to kinesiotaping, and refused to follow all instructions. Subjects would be drop-out if did not come for application kinesiotaping once, did not come to hand motor exercise two times, and did not come on assessment (baseline and end of the study). All participant filled inform consent as agreement by their parents.

The sample was chosen by simple random sampling. Subjects who met the criteria in the study were included according to sampling calculation. Participant will not include on analysis (drop out) if they did not come for applying kinesiotaping on schedule once, did not come for hand motor exercise two times, 
and did not come on outcome assessment at baseline and final assessment.

The aims and procedures of the study were explained to the parents or caregivers first, before they sign the informed consent for their child's participation. We performed allergic test with a patch of kinesiotaping on the dorsum of the participant's hand. There were 18 children who were divided into KT group and control group. Subjects in KT group received hand motor exercise and wrist kinesiotaping on wrist extensor muscle and thumb. While subjects in control group received only hand motor exercise. Both groups received hand motor exercise three times a week for 4 weeks.

Two kinesiotapings were applied to the patient, on wrist and thumb. Researchers had prepared kinesiotaping I strip measuring $5 \mathrm{~cm}$, and kinesiotaping II with strip tape measuring 2-2.5 $\mathrm{cm}$. The researcher positioned the patient's arm in the elbow extension position and wrist. Then the distance from the lateral epicondyle to the metacarpophalangeal joint (MCP) of the radius was measured. The skin was cleaned by $70 \%$ alcohol before application the kinesiotaping. The kinesiotaping was applied from lateral epicondyle to MCP joint on the second to fifth fingers with $30 \%$ traction. It was then rubbed so that it was firmly attached to the dorsum of the hand. Then, for the thumb $\mathrm{KT}$, we measured the distance from the origin of the extensor and abductor policis longus (distal third of the forearm) to the MCP joint of the thumb. It was applied from the origo extensor and abductor policis longus (distal third of the forearm) to the MCP joint of the thumb with $30 \%$ traction.

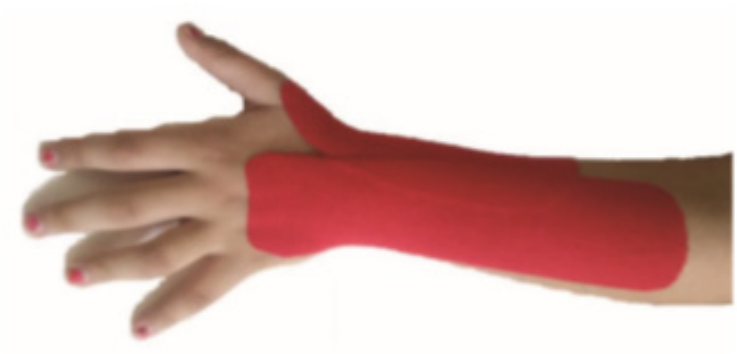

Figure 1. The application of kinesiotaping

The kinesiotaping was kept for 3 days on the child's hand. The kinesiotaping was removed after 3 days. After 24 hours removing, the new kinesiotaping was applied for the next 3 days. The placement was carried out by the researcher and the release was carried out by the patient's family. Kinesiotaping was applied 30 minutes before training. Hand motor exercise was done $3 \mathrm{x} /$ week for 4 weeks on Monday, Wednesday, and Friday.

Hand motor exercise included flexor wrist stretching exercises and wrist extensor muscle strengthening exercises that are actively performed for 45 minutes / session. Stretching exercises was performed before the extensor wrist muscle strengthening exercise $3-5 x$ repetition, held for 40-60 seconds. Extensor wrist strengthening exercises used hand putty, nine hole peg board and ball. Exercises with a putty and a nine hole peg board are carried out in an upright sitting position with subject's hands resting on the table.

The forearm is held during the exercise in such a way as to allow for wrist extension motion. Exercises with the ball are done in a sitting position leaning back, hands on the table, wrist extension and the ball squeezed. The exercise is repeated for 10 repetition and 2-3 sets. Rest between exercises is given for 2 minutes. 
Changes in fine motor skills that obtained through MACS score were the outcome measurements. Pre and posttest scores were collected before applying kinesiotaping and after 4 weeks of intervention. MACS consist of five levels. These levels are based on how children with cerebral palsy handle or manipulate objects and also whether they need help or assistance to do daily manual activities. $^{10}$ Level I for the children with minimal limitations and no need assistance, while levels $\mathrm{V}$ include children with severe functional limitations that required total assistance. The leaflet of MACS that we used in this study as seen in Table 1 and also available on http://www.macs.nu.

Table I. Description Manual Ability Classification System (MACS) Level

\begin{tabular}{cl}
\hline LEVEL & \multicolumn{1}{c}{ DESCRIPTION } \\
\hline I & Handles objects easily and successfully \\
& At most, limitations in the ease of performing manual tasks requiring speed and \\
accuracy. However, any limitations in manual abilities do not restrict independence in \\
daily activities.
\end{tabular}

Independent t-test, paired t test, and wilcoxon test were performed to compare MACS scores before and after intervention and the differences of MACS score between both groups. Data were analyzed using SPSS ${ }^{\circledR}$ version 20. P value $<0.05$ with confidence interval $95 \%$ was considered statistically significant.

\section{RESULTS}

This study began with research dissemination and informed consent request, then an initial assessment of the MACS score was carried out. The intervention started on 5 August 2019 and ended on 2 September 2019. The study was done for 4 weeks with 12 training sessions 
(3 times per week). For KT group, the number of taping installations performed for 4 weeks was 7 times. The assessment of MACS score after the intervention was obtained on last day in fourth week intervention on September 2nd 2019. Until the end of the study, the overall data analyzed were 18 participants. The characteristic of participants such as sex, age, BMI, IQ, cerebral palsy type, and ashworth scale were collected at baseline. The baseline data of participants in this study are shown in Table 2. Both groups are homogeneous and there was no significant difference.

Table 2. Characteristic of the subjects

\begin{tabular}{lccc}
\hline \multicolumn{1}{c}{ Variable } & \multicolumn{2}{c}{ Group } & p \\
\hline Sex & Kinesiotaping (KT) & Control & $1.000^{\ddagger}$ \\
$\quad$ Male & $5(55.6 \%)$ & $5(55.6 \%)$ & \\
Female & $4(44.4 \%)$ & $4(44.4 \%)$ & $0.829^{\S}$ \\
Age & $10.78 \pm 2.17 ; 11(8-14)$ & $10.56 \pm 2.13 ; 10(8-14)$ & $0.866^{\S}$ \\
BMI & $17.04 \pm 4.33$ & $16.66 \pm 5.05$ & $0.222^{\S}$ \\
IQ & $60.00 \pm 9.62$ & $54.33 \pm 9.30$ & \\
Cerebral palsy type & & & $0.842^{\ddagger}$ \\
Hemiplegi & $2(22.2 \%)$ & $3(33.3 \%)$ & \\
Diplegi & $4(44.4 \%)$ & $3(33.3 \%)$ & \\
Quadriplegi & $3(33.3 \%)$ & $3(33.3 \%)$ & \\
Ashworth scale & & & \\
1 & $2(22.2 \%)$ & $1(11.1 \%)$ & \\
$1+$ & $1(11.1 \%)$ & $4(44.4 \%)$ & \\
2 & $6(66.7 \%)$ & $4(44.4 \%)$ & \\
& & &
\end{tabular}

Note : * Significant $(\mathrm{p}<0.05) ; ¥$ Chi square; $§$ Independent $\mathrm{t}$

In table 3, the subjects in KT group had MACS score II and III were 3 children and 6 children, respectively. While in the control group the subjects who had MACS score II and III were 3 children and 6 children, respectively.

After four weeks intervention, there was improvement on MACS score in the KT group from MACS scores II to I and from MACS score III to II as 1 child and 4 children, respectively.
We used wilcoxon test to compare MACS score pre and posttest, and found a significant difference in the KT group $(\mathrm{p}=0.025)$.

There was improvement of MACS score in control group from score II to I and MACS score III to II as 1 child and 2 children, respectively. However, this improvement was not statistically significant. $(\mathrm{p}=0.083)$ 
Table 3. MACS score between groups

\begin{tabular}{lcccccc}
\hline \multirow{2}{*}{ Group } & MACS pre & I & II & III & Total & p $\dagger$ \\
\hline Kinesiotaping group & II & 1 & 2 & 0 & 3 & $0.025^{*}$ \\
\multirow{2}{*}{ Control group } & III & 0 & 4 & 2 & 6 & \\
& II & 1 & 2 & 0 & 3 & 0.083 \\
& III & 0 & 2 & 4 & 6 & \\
\hline
\end{tabular}

* Significant $(\mathrm{p}<0.05) ; \uparrow$ Wilcoxon

\section{DISCUSSION}

Based on the baseline data on the characteristics of subjects, it shows that the characteristics of subjects in both groups were not statistically significant difference for sex, age, BMI, IQ score, type of cerebral palsy, spasticity as measured by the Asworth scale. It showed that the characteristics of the research subjects in this two groups are homogeneous, so they would not affect the results of the study.

The result of the study in fine motor skill after 4 weeks hand motor exercise was found improved on KT group statistically significant. The similar results were also found in a study by Roy $^{5}$ which studied 60 children with cerebral palsy and then applied kinesiotaping over the forearm from lateral epicondyle of elbow to the tip of fingers, over the muscles belly of extensor muscle. They used MACS and Peabody development of motor skills (PDMS) to asses fine motor skills. After 1 month of application kinesiotaping together with conventional occupational therapy, the MACS and PDMS scores were increased after the intervention. Then after statistical analysis, there was significant improvement of MACS scores for the KT group and control group.

The application of kinesiotaping as an additional therapy to rehabilitation program for children with $\mathrm{CP}$ can assist in strategies to achieve goal therapy to improve the function of hand in children with CP. Kinesiotaping will stimulate skin mechanoreceptors through pressure and stretch resulting in physiological changes in increasing muscle activity and recruitment of firing motor units. The increasing use of motor muscle units as a result of proprioceptive stimulation may improves motor performance. Besides controlling the wrist and forearm joints, the control of the thumb and fingers will be better so that it facilitates more functional wrist movements. ${ }^{6,12}$

Kinesiotaping also increased kinesthetic input and facilitated the increased control in the wrist and forearm muscles while improving control the movements of muscle and tendon during activities. Because we applied the kinesiotaping on the wrist extensor, it may increases hand grip and hand manual ability, and also improving fine motor skill. 
In this study, kinesiotaping was applied from lateral epicondyle (origin) to the $\mathrm{MCP}$ joint (insertion) with $30 \%$ traction. KT may stimulate the reflex contraction of muscle spindle and facilitate the muscle contraction when it is attached from origin to insertion. This concept is based on cutaneous afferent signals thought to be associated with this proprioceptors affecting the motor unit excitability as well as the proprioceptive reflex loops. ${ }^{12}$

As far as we know several existing studies have evaluated the short-term effects of applying wrist kinesiotaping in children with $\mathrm{CP}$, but no one has yet known its long-term effects. The effect of applying kinesiotaping on hand motor exercise in this study showed significant results after 4 weeks of installation. Chitaria et al. ${ }^{4}$ studied 15 children with $\mathrm{CP}$ and examined the short term effects of $\mathrm{KT}$ in fine motor skill. They studied the kinesiotaping effects on fine motor function after 3 days using Peabody Developmental Motor Scale (PDMS-2). They found significant differences in fine motor PDMS-2 scores on baseline data, on application of tape, three days before tape removal and after removal.

In contrast to our study, the experimental study by Razti ${ }^{6}$ in thirty two children with $\mathrm{CP}$ who was given kinesiotaping in both groups for 2 days. The intervention group received kinesiotaping that was applied from the origin of the extensor and abductor policis longus to the metacarpal joint in the thumb with $30 \%$ tension in the muscle area and $75 \%$ in the joint area, while the control group was using KT in same method but without any tension. They assessed the short-term effects of kinesiotaping on handgrip and wrist range of motion right after taping, 2 days after, and 2 days after the tape was removed.

Cerebral palsy (CP) causes difficulty in reaching and grasping activities of the affected upper extremity thus resulting in poor fine motor skill. It can be seen in recent study by S. Pandit ${ }^{13}$ that studied the effect of KT on fine motor and gross motor skill. They studied in 20 children with hemiplegic $\mathrm{CP}$ after 3 days. The intervention group was received conventional therapy and kinesiotaping while control group was received conventional therapy only. For outcome measurement, they evaluated the Quality of upper extremity skills test (QUEST). Both groups were evaluated before, immediately after tape application, and 3 days later. There were no statistical difference in final QUEST scores between the two groups.

In this study, for assessing fine motor skill children with $\mathrm{CP}$, we used MACS score. MACS is used for classifying the typical way of handles things in child with CP during daily activities. ${ }^{14}$ The MACS was reliably for 4 - 18 years old children and $18-24$ years old ${ }^{11}$, and in this study, the participants were 8 until 14 years old.

Moreover, the reliability and validity of MACS is good for cerebral palsy. ${ }^{10,11}$ It was tested among therapists for 168 children with CP between 4-18 years and between therapists and parents. Score was 0.96 for the intraclass correlation coefficient among therapists, while between therapist and parents the score was $0.96(0.89-0.98)$ that means the excellent agreement. ${ }^{10}$ 
The limitation of this study is the timing of the assessment which is only done after 4 weeks of using kinesiotaping. The significant improvement of fine motor skills in the subjects in this study, may not concluded the long-term effects of kinesiotaping. For this reason, we suggests the further study of the effect of kinesiotaping with a longer period of time

\section{CONCLUSION}

Wrist kinesiotaping can be used for additional therapy to conventional hand motor exercise in children with CP. It may increasing hand grip and manual ability in the hand, and improving fine motor skill. This is shown by the increasing MACS score in children who were received application of wrist kinesiotaping and hand motor exercise for 4 weeks. However, the long-term effect of wrist kinesiotaping on fine motor skills in cerebral palsy, has been still unknown.

\section{REFERENCES}

1. Stark, Stacy M. Cerebral Palsy. In: Frontera WR, Silver JK, Rizzo TD, editors. Essential of Physical Medicine and Rehabilitation. Fourth edition. Elsevier; 2019. p. 689-96.

2. Makki D, Duodu J, Nixon M. Prevalence and pattern of upper limb involvement in cerebral palsy. J Child Orthop 2014; 8: 215-9.

3. Sara J, Cuccurullo M. Cerebral Palsy. In: Physical Medicine and Rehabilitation Board Review. New York: Demos Medical; 2015. p. 782-99.
4. Chitaria SB, Narayan A, Ganesan S. Shortterm effects of kinesiotaping on fine motor function in children with cerebral palsy-a quasi experimental study. Crit Rev Phys Rehabil Med 2015; 27(1): 41-50.

5. Roy S, Dixit J, Kumar A, Singh O. The Effect of Kinesiotaping in Improving Fine Motor Skills In Children With Spastic Diplegic Cerebral Palsy. IOSR-JDMS 2018; 17(11): 79-84.

6. Rasti ZA, Shamsoddini A, Dalvand H, Labaf S. The Effect of Kinesio Taping on Handgrip and Active Range of Motion of Hand in Children with Cerebral Palsy. Iran J Child Neurol Autumn 2017; 11(4): 43-51.

7. Cunha AB, Lima-Alvarez CD, Rocha ACP, Tudella E. Effects of elastic therapeutic taping on motor function in children with motor impairments: a systematic review. Disabil Rehabilitation 2017; 1464-5165. DOI:10.1080/09638288.2017.1304581

8. Morris D, Jones D, Ryan H, Ryan CG. The clinical effects of KinesioVR Tex taping: a systematic review. Physiother Theory Pract 2013; 29: 259-70.

9. Konishi Y. Tactile stimulation with Kinesiology tape alleviates muscle weakness attributable to attenuation of Ia afferents. J Sci Med Sport 2013; 16: 45-8.

10. Eliasson AC, Krumlinde-Sundholm L, Rosblad B, Beckung E, Arner M, Ohrval AM, et al. The Manual Ability Classification System (MACS) for children with cerebral palsy: scale development and evidence of validity and reliability. Dev Med Child Neurol 2006; 48: 549-54.

11. Jeevanantham D, Dyszuk E, Bartlett D. The Manual Ability Classification 
System: A Scoping Review. Pediatr Phys Ther 2015; 27(3): 236-41. DOI:10.1097/ pep.0000000000000151

12. Yeung SS, Yeung EW. Acute Effects of Kinesio Taping on Knee Extensor Peak Torque and Stretch Reflex in Healthy Adults. Medicine (Baltimore) 2016; 95(4): e2615.

13. Pandit S, Bisen R. Effect Of Kinesiotaping On The Quality Of Upper Extremity
Function In Children With Hemiplegic Cerebral Palsy-An Experimental Study. Natl J Integr Res Med 2020; 11: 5.

14. Duff S, Wolff A. Fine Motor Skill Development in Children and Youth with Unilateral Cerebral Palsy. In: F. Miller et al, editors. Cerebral Palsy. Springer Nature Switzerland AG; 2018. DOI: https://doi. org/10.1007/978-3-319-50592-3_170-1. 